\title{
Nutritional composition and fermentative characteristics of Massai grass silage added with licuri (Syagrus coronata) cake
}

\section{Composição nutricional e características fermentativas da silagem de capim Massai adicionada com torta de licuri (Syagrus coronata)}

\author{
Ronaldo Lopes Oliveira ${ }^{1 *}$; Ossival Lolato Ribeiro ${ }^{2}$; Adriana Regina Bagaldo²; \\ Máikal Souza Borja ${ }^{3}$; Bráulio Rocha Correia ${ }^{4}$; Luciano dos Santos Lima ${ }^{5}$; \\ Henry Daniel Ruiz Alba ${ }^{5}$; Vagner Maximino Leite ${ }^{1}$ Leilson Rocha Bezerra ${ }^{6}$,
}

\begin{abstract}
This study evaluated the best level of inclusion of licuri cake (Syagrus coronata) in massai grass (Megathyrsus maximus) silage by chemical composition and fermentation quality of the silage. The experiment was conducted at Experimental Farm of the School of Veterinary Medicine and Animal Science of Federal University of Bahia. The treatments were composed by massai grass cut at 40 days, chopped and added at levels 0, 80, 160 and $240 \mathrm{~g} \mathrm{~kg} \mathrm{DM}^{-1}$ of licuri cake. After mixing, the material was compressed in experimental silos, which were opened after 76 days. The experimental design was completely randomized, with four treatments and four replications. Data were analyzed by analysis of variance and regression. The addition of licuri cake improve linear increase $(P<0.01)$ in the contents of dry matter, crude protein, ether extract, total digestible nutrients, $\mathrm{pH}, \mathrm{NH}_{3}-\mathrm{N}$, dry matter intake, digestible dry matter and forage value index in massai grass silage There was a linear reduction in the contents of ash, neutral detergent fiber, acid detergent fiber, hemicellulose and cellulose $(P<0.01)$. There were no differences on contents non-fibrous carbohydrates $(P=0.356)$ and acid detergent lignin $(P=0.432)$. It is recommended the inclusion of licuri cake at level of $240 \mathrm{~g} \mathrm{~kg} \mathrm{DM}^{-1}$ in massai silage, because provided the greatest chemical composition, dry matter intake, digestible dry matter and forage value index.
\end{abstract}

Key words: Additive. Biofuel. Ensilage. Forage conservation. Nutrition.

\section{Resumo}

Este estudo avaliou o melhor teor de inclusão da torta de licuri (Syagrus coronata) em silagem de capim massai (Megathyrsus maximus) através da composição química e qualidade de fermentação da silagem. O experimento foi conduzido na Fazenda Experimental da Faculdade de Medicina Veterinária e Zootecnia da Universidade Federal da Bahia. Os tratamentos foram compostos por capim massai cortado aos 40 dias e a adição de torta de licuri nos teores $0,80,160$ e $240 \mathrm{~g} \mathrm{~kg}^{-1}$ de MS. Após a mistura,

\footnotetext{
1 Profs., Escola de Medicina Veterinária e Zootecnia, Universidade Federal da Bahia, UFBA, Salvador, BA, Brasil. E-mail: ronaldooliveira@ufba.br; vagnerleite@ufba.br

2 Profs., Departamento de Zootecnia, UFRB, Cruz das Almas, BA, Brasil, E-mail: ossival@ufrb.edu.br; arbagaldo@ufrb.edu.br

3 Pesquisador, Escola de Medicina Veterinária e Zootecnia, UFBA, Salvador, BA, Brasil. E-mail: maikal.borja@gmail.com

4 Pesquisador, Departamento de Zootecnia, Universidade Federal do Recôncavo da Bahia, UFRB, Cruz das Almas, BA, Brasil, E-mail: braulio@zootecnista.com.br

5 Discentes, Escola de Medicina Veterinária e Zootecnia, UFBA, Salvador, BA, Brasil. E-mail: luciano_lslima@hotmail.com; harrydoo@gmail.com

6 Prof., Departmento de Zootecnia, Universidade Federal do Piauí, UFPI, Bom Jesus, PI, Brasil. E-mail: leilson@ufpi.edu.br

Author for correspondence
} 
o material foi conservado em silos experimentais, que foram abertos após 76 dias. O delineamento experimental foi inteiramente casualizado, com quatro tratamentos e quatro repetições. Os dados foram analisados por análise de variância e regressão. A adição de torta de licuri promoveu incremento linear $(P<0,01)$ nos teores de matéria seca, proteína bruta, extrato etéreo, nutrientes digestíveis totais, $\mathrm{pH}$, $\mathrm{N}-\mathrm{NH}_{3}$, ingestão de matéria seca, matéria seca digestível e índice de forragem da silagem de capim massai. Houve uma redução linear nos teores de cinzas, fibra em detergente neutro, fibra em detergente ácido, hemicelulose e celulose $(P<0,01)$. Não houve diferenças no conteúdo de carboidratos não fibrosos $(P=0,356)$ e lignina $(P=0,432)$. Recomenda-se a inclusão de $240 \mathrm{~g} \mathrm{~kg}^{-1}$ de MS de torta de licuri em silagem massai, pois proporciona melhora na composição química, no consumo de matéria seca, na matéria seca digestível e no índice de valor de forragem.

Palavras-chave: Aditivo. Biocombustível. Conservação de forragem. Ensilagem. Nutrição.

\section{Introduction}

The use of cultivated perennial pastures is an alternative way of meeting the feed requirements of grazing animals (WILSON et al., 2014). However, seasonality in forage production resulting from the presence of rainy and dry seasons requires the use of alternate strategies to meet animal feed requirements throughout the year in pasture-based livestock farming (ÖZKAN et al., 2014). The problems resulting from the seasonality of forage production can be minimized by storing forage as silage. In recent years, there has been increasing interest in the use of forage grasses for the production of silage; according to Carvalho et al. (2008), this method is an alternative to roughage conservation when feeding animals in feedlots or during periods of food scarcity.

The intrinsic is characteristics of tropical forage plants, genus Panicum for exemple, harvested at the ideal stage for cutting (great moisture content, low soluble carbohydrate content), and tropical grass silages may experience energy and dry matter losses varying from 70 to $400 \mathrm{~g} \mathrm{~kg}^{-1}$ due to secondary fermentation and aerobic deterioration (BERNARDES et al., 2015). One way of minimizing this problem is to add materials with great dry matter (FERREIRA et al., 2016).

Thus, various byproducts are increasingly available and are being evaluated as alternative feed sources (GONZAGA NETO et al., 2015), the use of Licuri Palm (Syagrus coronata), a licuri cake is obtained; this cake can be marketed as an animal feed containing190-250 $\mathrm{g} \mathrm{kg}^{-1}$ protein, $120 \mathrm{~g} \mathrm{~kg}^{-1}$ ether extract and $900 \mathrm{~g} \mathrm{~kg}^{-1} \mathrm{DM}$ and your cake can be used as silage additive for increase dry matter. In this way, the addition of the licuri cake in massai grass (Megathyrsus maximus) silage, an addition that aims to correct the DM of the plant, could reduce nutrient losses in effluents by reducing the moisture content and provide greater fermentation process efficiency by anaerobic bacteria. Therefore, the objective of this study was to evaluate the effect of the inclusion of licuri cake on the fermentation profile and chemical composition of massai grass silage.

\section{Materials and Methods}

\section{Ethical considerations}

This study was carried out in strict accordance with the recommendations in the Guide for the National Council for Animal Experiments Control. The protocol was approved by the Committee on the Ethics of Animal Experiments of the Federal University of Bahia, Bahia, Brazil (Permit Number: 17-2014).

\section{Study site}

The experiment was conducted in Experimental Farm of the School of Veterinary Medicine and Animal Science, Federal University of Bahia (Universidade Federal da Bahia - UFBA), located in São Gonçalo dos Campos city (12 $25^{\circ}$ "58' South, $38^{\circ} 58^{\prime \prime} 01^{\prime}$ West) in the Bahia State. After 40 days of growth, the massai grass was manually cut at a height of $10 \mathrm{~cm}$ from the soil and ground into $4-\mathrm{cm}$ fragments in a stationary grinder. 


\section{Experimental silos}

The treatments were composed of massai grass supplemented with licuri cake at rates of 80,160 and $240 \mathrm{~g} \mathrm{~kg} \mathrm{DM}^{-1}$ fresh matter (FM) weight, as well as a control treatment without the cake; four replicates per treatment were used for a total of 16 experimental units. After homogenization of the treatments, 15-L polyethylene buckets (silos) were used to ensile the material. The silos were so compacted and sealed with plastic tape ( $1 \mathrm{~m}$ wide, $2 \mathrm{~m}$ long and $150 \mu \mathrm{m}$ thick) to prevent the entry of air. Subsequently, the silos were stored in a covered barn at environmental temperature and protected from rain and sunlight. After 76 days, the experimental silos were opened, and after discarding the edges, samples were taken from the center of each experimental unit, placed in plastic bags and stored in a freezer until further analysis.

\section{Chemical analysis}

Samples of silage and ingredients were pre-dried in an oven at $55^{\circ} \mathrm{C}$ for 72 hours and ground in a knife mill using a 1-mm sieve and it's were determine according AOAC (1990) by dry matter (DM, Method 967.03), ash (Method 942.05), crude protein (CP, Method 981.10), and ether extraction (EE, Method 920.29).

To determine the hemicellulose (HEM), neutral detergent fiber (NDF) and acid detergent fiber (ADF) contents, the methodology of Van Soest et al. (1991) was used with the modifications that were proposed in the Ankon device manual (Ankon Technology Corporation, Macedon, New York, US). Acid detergent lignin (ADL) was determined according to AOAC method 973.18 (1990), in which the ADF residue was treated with $72 \%$ sulfuric acid. The non-fibrous carbohydrates (NFC) were obtained according to Mertens (1997). Total digestible nutrients (TDN) were estimated according to NRC (2001): $\mathrm{TDN}=\mathrm{CPD}+(\mathrm{EED} \times 2.25)+\mathrm{NDFD}+$ NFCD; where: $\mathrm{CPD}=$ crude protein digestible; $\mathrm{EED}$ $=$ ether extract digestible; NDFD = neutral detergent fiber digestible; NFCD = non-fibrous carbohydrates digestible. The chemical composition of the licuri cake and massai grass are shown in Table 1.

Table 1. Chemical composition ( $\mathrm{g} \mathrm{kg}^{-1}$ ) of the massai grass (Megathyrsus maximus) and licuri cake (Syagrus coronata).

\begin{tabular}{lcc}
\hline \multicolumn{1}{c}{ Chemical composition } & Massai grass & Licuri cake \\
\hline Dry matter, $\mathrm{g} \mathrm{kg}^{-1}$ as fed & 213 & 956 \\
Ash, $\mathrm{g} \mathrm{kg}^{-1} \mathrm{DM}$ & 93.0 & 74.2 \\
Crude protein, $\mathrm{g} \mathrm{kg}^{-1} \mathrm{DM}$ & 64.0 & 236 \\
Ether extract, $\mathrm{g} \mathrm{kg}^{-1} \mathrm{DM}$ & 7.22 & 101 \\
Neutral detergent fiber, $\mathrm{g} \mathrm{kg}^{-1} \mathrm{DM}$ & 677 & 515 \\
Acid detergent fiber, $\mathrm{g} \mathrm{kg}^{-1} \mathrm{DM}$ & 486 & 349 \\
Acid detergent lignin, $\mathrm{g} \mathrm{kg}^{-1} \mathrm{DM}$ & 104 & 173 \\
Cellulose, $\mathrm{g} \mathrm{kg}^{-1} \mathrm{DM}$ & 382 & 176 \\
Hemicellulose, $\mathrm{g} \mathrm{kg}^{-1} \mathrm{DM}$ & 191 & 167 \\
Non-fiber carbohydrate, $\mathrm{g} \mathrm{kg}^{-1} \mathrm{DM}$ & 159 & 74.2 \\
Insoluble Nitrogen neutral detergent, $\mathrm{g} \mathrm{kg}^{-1} \mathrm{CP}$ & 300 & 400 \\
Insoluble Nitrogen acid detergent $\mathrm{g} \mathrm{kg}^{-1} \mathrm{CP}$ & 50.3 & 278 \\
\hline
\end{tabular}




\section{Fermentation parameters}

The $\mathrm{NH}_{3}-\mathrm{N}$ content, as a percentage of the total nitrogen, was estimated according to Cunniff (1995). The $\mathrm{pH}$ values of the silages in the respective treatments were determined using a digital potentiometer after the silos were opened (SILVA; QUEIROZ, 2002).

The forage value index was obtained using the equations described (TEIXEIRA; ANDRADE, 2001):

Equation 1: DMI (\% live weight $)=120 / \mathrm{NDF} g$ $\mathrm{kg}^{-1}$ of DM;

Equation 2: DDM $(\%)=88.9-0.779 \times \mathrm{ADF} g$ $\mathrm{kg}^{-1}$ of DM;

Equation 3: FVI $=(\mathrm{DMI} \times \mathrm{DDM}) / 1.29$,

Where: DMI ( $\mathrm{g} \mathrm{kg}^{-1}$ body weight $)=120 / \mathrm{NDF}$ of forage DM (equation 1); DDM $\left(\mathrm{g} \mathrm{kg}^{-1}\right)=88.9$ $0.779 \times \mathrm{g} \mathrm{kg}^{-1} \mathrm{ADF}$ of the forage DM (equation 2); $\mathrm{FVI}=(\mathrm{DMI} \times \mathrm{DDM}) / 1.29$ (equation 3$)$, where DMI (dry matter intake), NDF (fiber detergent), DDM (digestible dry matter), DM (dry matter), ADF (acid detergent fiber), FVI (forage value index).

Dry matter digestibility (DDM) was obtained after $48 \mathrm{~h}$ of in vitro fermentation in bottles with a capacity of $160 \mathrm{~mL}$, using culture medium according to the recommendations of Theodorou et al. (1994). Approximately $0.3 \mathrm{~g}$ of sample was introduced into the fermentation vials and to this was added $30 \mathrm{ml}$ of buffered culture medium. The ruminal liquid used was obtained from a Santa Inês sheep weighing approximately $30 \mathrm{~kg}$, with three years old, with a permanent ruminal cannula and adapted to the proposed diet. After collection the ruminal liquid was filtered in a double layer of gauze and stored in a preheated thermos flask until use in the laboratory. Dry matter intake (DMI) was also determined by the difference between supply and leftovers for 15 days.

\section{Statistical analysis}

The experimental design was completely randomized with four treatments $(0,80,160$, and $240 \mathrm{~g} \mathrm{~kg} \mathrm{DM}^{-1}$ of licuri cake inclusion in massai silage) and four replicates per treatment. The data were subjected to an analysis of variance and regression analyses (linear and quadratic) using the GLM and REG procedures implemented in SAS ${ }^{\circledR}$ statistical software (version 9.1.2. Cary, NC, USA). The significance level was set at a probability of 5\% $(P \leq 0.05)$,

\section{Results}

The licuri cake had great moisture-absorption potential, as its addition led to a linear increase $(P$ $<0.05$ ) in the DM content of the silage (Table 2). In the present study, DM level exceeding $250 \mathrm{~g} \mathrm{~kg}^{-1}$ were observed with $80 \mathrm{~g} \mathrm{~kg} \mathrm{DM}^{-1}$ inclusion of the additive in the silage. The DM values exceeding $350 \mathrm{~g} \mathrm{~kg}^{-1}$ were observed when the silage contained $160 \mathrm{~g} \mathrm{~kg} \mathrm{DM}^{-1}$ of the additive. A linear increase $(P$ $<0.05)$ in the $\mathrm{CP}$ content of the silage was observed with the addition of the licuri cake.

The massai grass silage had $64 \mathrm{~g} \mathrm{~kg}^{-1} \mathrm{CP}$ in the absence of the additive; adding $240 \mathrm{~g} \mathrm{~kg} \mathrm{DM}^{-1}$ of licuri cake raised the $\mathrm{CP}$ content of the silage to $163 \mathrm{~g} \mathrm{~kg}^{-1}$. For every $10 \mathrm{~g} \mathrm{~kg} \mathrm{DM}^{-1}$ inclusion of licuri cake, a $4 \mathrm{~g} \mathrm{~kg} \mathrm{CP}^{-1}$ increase in the silage was observed. The percentage of ether extract (EE) of the silage increased linearly $(P<0.05)$ with the addition of licuri cake. For each $10 \mathrm{~g} \mathrm{~kg} \mathrm{DM}^{-1}$ inclusion of licuri cake, a $70 \mathrm{~g} \mathrm{~kg}^{-1}$ increase in EE was observed.

The inclusion of the licuri cake contributed reduce $(P<0.05)$ the NDF and ADF levels in the silage (Table 2). For every $10 \mathrm{~g} \mathrm{~kg} \mathrm{DM}^{-1}$ addition of the cake, reductions of $37 \mathrm{~g} \mathrm{~kg}^{-1}$ and $24 \mathrm{~g} \mathrm{~kg}^{-1}$ in NDF and ADF, respectively, were observed. The inclusion of licuri cake contributed to a reduction $(P$ $<0.05)$ in the hemicellulose (HEM) and cellulose 
(CEL) contents of massai grass silage too: for each $10 \mathrm{~g} \mathrm{~kg} \mathrm{DM}^{-1}$ addition of cake, reductions of 13 and $27 \mathrm{~g} \mathrm{~kg}^{-1}$ in HEM and CEL, respectively, were observed.

Table 2. Means, significance ( $P$-value) and coefficients of variation (CV\%) of chemical composition of the massai grass (Megathyrsus maximus) silage added licuri cake (Syagrus coronata).

\begin{tabular}{lccccccc}
\hline \multirow{2}{*}{ Chemical composition $\left(\mathrm{g} \mathrm{kg}^{-1} \mathrm{DM}\right)$} & \multicolumn{9}{c}{ Licuri cake levels $\left(\mathrm{g} \mathrm{kg} \mathrm{DM}^{-1}\right)$} & \multicolumn{2}{c}{$P$-value } & \multirow{2}{*}{$\mathrm{CV}^{\ddagger}(\%)$} \\
\cline { 2 - 7 } & 0 & 80 & 160 & 240 & Linear & Quadratic & \\
\hline Dry matter, g kg-1 as fed & 241 & 304 & 366 & 428 & $<0.01$ & 0.73 & 7.79 \\
Ash & 117 & 103 & 89.6 & 76.0 & $<0.01$ & 0.92 & 10.54 \\
Crude protein & 61.2 & 94.8 & 128 & 162 & $<0.01$ & 0.63 & 13.22 \\
Ether extract & 13.2 & 18.8 & 24.4 & 30.0 & $<0.01$ & 0.46 & 12.65 \\
Neutral detergent fiber & 684 & 714 & 743 & 773 & $<0.01$ & 0.94 & 8.96 \\
Acid detergent fiber & 473 & 492 & 512 & 531 & $<0.01$ & 0.77 & 10.58 \\
Hemicellulose & 218 & 228 & 239 & 249 & $<0.01$ & 0.22 & 7.69 \\
Cellulose & 345 & 367 & 389 & 410 & $<0.01$ & 0.18 & 8.11 \\
Non-fibrous carbohydrate & 110 & 81.5 & 161 & 126 & 0.356 & 0.38 & 14.53 \\
Acid detergent lignin & 131 & 124 & 136 & 135 & 0.432 & 0.98 & 6.33 \\
Total digestibles nutrientes & 402 & 429 & 457 & 484 & $<0.01$ & 0.69 & 5.44 \\
\hline
\end{tabular}

$\$ P$-value significant at $P<0.05$

$\uparrow \mathrm{CV}$ : Coefficient of variation.

A decreasing trend was observed for non-fibrous carbohydrates (NFC) and acid detergent lignin (ADL) levels with the $80 \mathrm{~g} \mathrm{~kg} \mathrm{DM}^{-1}$ addition of licuri cake, although the results were not statistically significant (Table 2). The control silage produced without the licuri cake had lignin contents similar to those of the other treatments $(P>0.05)$. Although the results did not differ significantly, the $160 \mathrm{~g} \mathrm{~kg}$ $\mathrm{DM}^{-1}$ addition of licuri cake resulted in increasing NFC levels in the massai grass silage. The concentration of total digestible nutrients (TDN) increased linearly $(P<0.05)$ with the addition of licuri cake to the silage. For every $10 \mathrm{~g} \mathrm{~kg} \mathrm{DM}^{-1}$ addition of the cake, an increase of $34 \mathrm{~g} \mathrm{~kg}^{-1}$ in TDN was observed.

The $\mathrm{pH}$ values (Table 3 ) presented quadratic dates $(P<0.05)$, and values within the range of 3.6 to 4.2 were found when using the additive. The lowest $\mathrm{pH}$ (3.99) was observed when the level of licuri cake was equal to $179 \mathrm{~g} \mathrm{~kg}^{-1}$ of DM. 
Table 3. Means, significance ( $P$-value) and coefficients of variation $(\mathrm{CV} \%)$ of $\mathrm{pH}$, amoniacal nitrogen $\left(\mathrm{NH}_{3}-\mathrm{N}\right)$, dry matter intake estimated (\%BW), digestible dry matter (\%) and forage value index (FVI) of the massai grass (Megathyrsus maximus) silage added licuri cake (Syagrus coronata).

\begin{tabular}{lccccccc}
\hline \multirow{2}{*}{ Variables } & \multicolumn{9}{c}{ Licuri cake levels $\left(\mathrm{g} \mathrm{kg} \mathrm{DM}^{-1}\right)$} & \multicolumn{2}{c}{$P$-value } & \multirow{2}{*}{$\mathrm{CV}^{\ddagger}(\%)$} \\
\cline { 2 - 7 } $\mathrm{pH}$ & 0 & 80 & 160 & 240 & Linear & Quadratic & \\
$\mathrm{NH}_{3}-\mathrm{N}\left(\mathrm{g} \mathrm{kg}^{-1}\right.$ of Total N) & 0.57 & 3.05 & 14.5 & 34.9 & $<0.01$ & 0.68 & 8.54 \\
Dry matter intake $(\% \mathrm{BW})$ & 153 & 183 & 316 & 551 & $<0.01$ & 0.42 & 7.58 \\
Dry matter digestible $\left(\mathrm{g} \mathrm{kg}^{-1}\right)$ & 1.74 & 1.84 & 1.93 & 2.00 & $<0.01$ & 0.27 & 4.68 \\
Forage value index & 518 & 536 & 557 & 562 & $<0.01$ & 0.70 & 4.77 \\
\hline
\end{tabular}

$\ddagger P$-value significant at $P<0.05$

$\uparrow \mathrm{CV}$ : Coefficient of variation.

In the present study, there was a quadratic reduction in the $\mathrm{NH}_{3}-\mathrm{N}$ values of the ensiled massai grass material $(P<0.05)$ : The lowest $\mathrm{NH}_{3}-\mathrm{N}$ content (129 $\mathrm{g} \mathrm{kg}^{-1}$ in crude protein basis) was observed for the $162 \mathrm{~g} \mathrm{~kg}^{-1} \mathrm{DM}$ of licuri cake.

The addition of licuri cake resulted in linear increases $(P<0.05)$ in dry matter intake $(\mathrm{DMI})$, digestible dry matter (DDM) and the forage value index (FVI) of massai grass silage. For every $10 \mathrm{~g}$ $\mathrm{kg} \mathrm{DM}^{-1}$ addition of licuri cake, increases of $0.01 \%$ and $1.9 \mathrm{~g} \mathrm{~kg}^{-1}$ were observed for DMI and DDM estimates, respectively. The supplementation with licuri cake resulted in a linear increase in the FVI of the massai grass silage. The greatest FVI was obtained with the $240 \mathrm{~g} \mathrm{~kg} \mathrm{DM}^{-1}$ addition of licuri cake to massai grass (87.25).

\section{Discussion}

The results obtained are evidence of the great potential of 40-day grown massai grass for ensilage. However, it is evident that the inclusion of licuri cake can increase the dry matter (DM) content of the silage and that, even at the optimal vegetative stage for grazing or cutting and despite its nutritional value; thus justifying the use of this cake as an efficient compound for moisture sequestration. Without the use of the additive, the DM content of the silage was $224 \mathrm{~g} \mathrm{~kg}^{-1}$, which is below the level recommended in the literature (ARRIOLA et al., 2015; GANCHE et al., 2015; LOPES et al., 2015; FERREIRA et al., 2016). Dry matter content (213 $\mathrm{g} \mathrm{kg}^{-1}$ as fed) of massai grass (Table 1) is not within the recommended range for ensiling. Dry matter concentration should be between 250 and $350 \mathrm{~g}$ $\mathrm{kg}^{-1}$ as fed to ensure the production of high-quality silage.

The increase in the crude protein can be explained by the greater protein concentration in the additive compared to that of the massai grass silage (Table 1). Regarding the content of ether extract, the NRC (2001) reports that the total fat in the diet should not exceed 60 to $70 \mathrm{~g} \mathrm{~kg}^{-1} \mathrm{DM}$, as greater levels may reduce rumen fermentation, fiber digestibility and passage rate. In the present study, none of the licuri cake inclusion levels resulted in EE levels above the range recommended by the NRC (2001) (Table 2). These results of NDF and ADF can be explained by the dilution effect caused by lower relative NDF and ADF levels in the additive than in the massai grass and by better fermentation of the silage material because massai grass with a shorter regrowth age (40 days) was harvested.

The increased levels of cellulose and hemicellulose in silages may be associated with a proportional reduction in soluble carbohydrate content and, therefore, dry matter due to the fermentation of soluble carbohydrates by different 
microorganisms present in silage (lactic acid bacteria and yeasts); these increases in HEM and CEL can result in extensive dry matter losses, which explain the proportional increase in fibrous matter.

It is important to state that an adequate NFC content (and, consequently, increased NFC in silage) is a desirable characteristic of silage additives of tropical forage plants, which generally have less than $100 \mathrm{~g} \mathrm{~kg} \mathrm{DM}^{-1}$ soluble carbohydrates and low buffering capacity (approximately $15 \mathrm{mg}$ HCL g $\mathrm{DM}^{-1}$ ); indeed, low levels of soluble carbohydrates do not provide sufficient fermentable substrate for lactic acid bacteria, which results in secondary fermentation and aerobic deterioration of the final product (BERNARDES et al., 2015).

The increase in the TDN concentration with the inclusion of licuri cake was most likely due to the chemical characteristics of this additive, which had elevated fractions of CP and EE (resulting in increased energy) and reduced fractions of NDF and ADF (which are inversely related to energy content) (Table 1) and produced reduced levels of NDF, ADF, hemicellulose and cellulose levels in the final product (Table 2). The $240 \mathrm{~g} \mathrm{~kg} \mathrm{DM}^{-1}$ addition of licuri cake resulted in silage with $477 \mathrm{~g} \mathrm{~kg}^{-1} \mathrm{TDN}$.

The effectiveness of the additives in improving silage quality can be explained by the supply of soluble carbohydrates, increased DM content or reduced buffering capacity of the forage, factors that directly influence fermentation and reduce silage $\mathrm{pH}$. In the present study, a considerable reduction in the $\mathrm{pH}$ of massai grass silage material $(P<0.05)$ was observed. The observed levels were sufficient for preserving the analyzed material (ZHANG et al., 2016). From $179 \mathrm{~g} \mathrm{~kg}^{-1}$ of DM content, the $\mathrm{pH}$ values rose but remained within the range considered optimal (MORAIS et al., 2015). These results indicate that there was adequate fermentation of ensiled mixtures, a desirable characteristic of the ensiling process.

The results also allow us to infer that the mixtures contained adequate amounts of soluble carbohydrates for the activity of lactic acid bacteria, resulting in lower $\mathrm{pH}$ values in the early hours of ensiling. In the present study, although the additive resulted in improvements to the chemical composition of the silage, $\mathrm{NH}_{3}-\mathrm{N}$ values were nevertheless greater than recommended in the literature. This result can be explained by the fact that the licuri cake has great protein content (236 $\mathrm{g} \mathrm{kg}^{-1}$ ), which can increase the buffering capacity during the ensiling process and therefore contribute to production of $\mathrm{NH}_{3}-\mathrm{N}$. The ammonia nitrogen $\left(\mathrm{NH}_{3}-\mathrm{N}\right)$ contents another parameter that must be taken into consideration (MEDEIROS et al., 2015), as it characterizes the adequacy of the silage fermentation process (ARNDT et al., 2015).

The linear increase in DMI and DDM can be explained by the effect of adding licuri cake to the ensiled material, resulting in increased $\mathrm{CP}$ and TDN levels and reduced fiber fractions (NDF, ADF, hemicellulose and cellulose) in the silage.

The increase in FVI is due to the association between the addition of licuri cake and the younger cutting age of the forage (40 days of regrowth), which results in a lower stem:leaf ratio and less activity of the extracellular matrix in converting parenchymal cells (rich in soluble carbohydrates) into sclerenchymal (constituent of the NDF and ADF fractions) (OLIVEIRA et al., 2015; SILVA et al., 2015). This leads to reductions in NDF and ADF in the ensiled material (Table 2), as these fractions are inversely related to the FVI.

\section{Conclusion}

Based on the results of the chemical compositional analysis and the $\mathrm{pH}$ and forage value index (but not the $\mathrm{NH}_{3}-\mathrm{N}$ content), it can be stated that an adequate fermentation process occurred in all treatments, especially those supplemented with the licuri cake. Hence, this byproduct of the oil extraction industry can be used as an additive in massai grass silage; its use may maximize the use of the licuri crop and produce a potentially better cost- 
benefit ratio for the use of this crop, although further studies may be required to confirm this hypothesis. The best inclusion level of licuri cake was $240 \mathrm{~g} \mathrm{~kg}$ $\mathrm{DM}^{-1}$, as it resulted in the greatest levels of DM, CP and TDN and in a greater forage value index and lower levels of fiber fraction in massai grass silage.

\section{References}

ARNDT, C.; POWELL, J. M.; AGUERRE, M. J.; WATTIAUX, M. A. Performance, digestion, nitrogen balance, and emission of manure ammonia, enteric methane, and carbon dioxide in lactating cows fed diets with varying alfalfa silage-to-corn silage ratios. Journal of Dairy Science, Illinois, v. 98, n. 1, p. 418-430, 2015.

ARRIOLA, K. G.; QUEIROZ, O. C. M.; ROMERO, J. J.; CASPER, D.; MUNIZ, E.; HAMIE, J.; ADESOGAN, A. T. Effect of microbial inoculants on the quality and aerobic stability of Bermuda grass round-bale haylage. Journal of Dairy Science, Illinois, v. 98, n. 1, p. 478-485, 2015.

ASSOCIATION OF OFFICIAL ANALYTICAL CHEMISTS - AOAC. Official methods of analysis. $15^{\text {th }}$ ed. Arlington: AOAC International, 1990. 1117 p.

BERNARDES, T. F.; OLIVEIRA, I. L.; LARA, M. A. S.; ASAGRANDE, D. R.; ÁVILA, C. L. S.; PEREIRA, O. G. Effects of potassium sorbate and sodium benzoate at two application rates on fermentation and aerobic stability of maize silage. Grass and Forage Science, Londres, v. 70, n. 3, p. 491-498, 2015.

CARVALHO, G. G. P. de; GARCIA, R.; PIRES, A. J. V.; DETMANN, E.; PEREIRA, O. G.; FERNANDES, F. E. P. Ruminal degradation of silage of elephant grass wilted or with different levels of cocoa meal. Revista Brasileira de Zootecnia, Viçosa, MG, v. 37, n. 1, p. 1347-1354, 2008.

CUNNIFF, P. Official methods of analysis of AOAC international. $16^{\text {th }}$ ed. Arlington: AOAC International, v. 1, $1995.57 \mathrm{p}$.

FERREIRA, R.; BEZERRA, L.; EDVAN, R.; ARAUJO, M.; MARQUES, C.; TORREÃO, J.; OLIVEIRA, R.; PARENTE, H. Physicochemical composition and ruminal degradability of leucaena ensiled with different levels of buriti fruit peel. Grassland Science, Tókio, v. 62, n. 3, p. 160-166, 2016.

GANCHE, E.; O’DONOVAN, M.; DELABY, L.; BOLAND, T. M.; KENNEDY, E. Does post-grazing sward height influence sward characteristics, seasonal herbage dry-matter production and herbage quality? Grass and Forage Science, Londres, v. 70, n. 1, p. 130143, 2015.

GONZAGA NETO, S.; OLIVEIRA, R. L.; LIMA, F. H. S.; MEDEIROS, A. N.; BEZERRA, L. R.; VIÉGAS, J.; NASCIMENTO JÚNIOR, N. G.; FREITAS NETO, M. D. Milk production, intake, digestion, blood parameters, and ingestive behavior of cows supplemented with byproducts from the biodiesel industry. Tropical Animal Health and Production, Edinburgh, v. 47, n. 1, p. 191200, 2015.

LOPES, F.; COOK, D. E.; COMBS, D. K. Validation of an in vitro model for predicting rumen and total-tract fiber digestibility in dairy cows fed corn silages with different in vitro neutral detergent fiber digestibilities at 2 levels of dry matter intake. Journal of Dairy Science, Illinois, v. 98, n. 1, p. 574-585, 2015.

MEDEIROS, F. F.; SILVA, A. M. A.; CARNEIRO, H.; ARAÚJO, D. R. C.; MORAIS, R. K. O.; MOREIRA, M. N.; BEZERRA, L. R. Alternative protein sources derived from the biodiesel production chain for feeding to ruminants. Arquivos Brasileiro de Medicina Veterinária e Zootecnia, Belo Horizonte, v. 67, n. 2, p. 519-526, 2015.

MERTENS, D. R. Creating a system for meeting the fiber requeriments of dairy cows. Journal of Dairy Science, Illinois, v. 80, n. 7, p. 1463-1481, 1997.

MORAIS, R. K. O.; SILVA, A. M. A.; BEZERRA, L. R.; CARNEIRO, H.; MOREIRA, M. N.; MEDEIROS, F. F. In vitro degradation and total gas production of byproducts generated in the biodiesel production chain. Acta Scientiarum Animal Science, Maringá, v. 37, n. 2, p. 143-148, 2015.

NATIONAL RESEARCH COUNCIL - NRC. Nutrient requirements of dairy cattle. $7^{\text {th }}$ ed. rev. Washington: National Academy Press, 2001. 450 p.

OLIVEIRA, R.; FARIA, M.; SILVA, R.; BEZERRA, L.; CARVALHO, G.; PINHEIRO, A.; SIMIONATO, J.; LEÃO A. G. Fatty acid profile of milk and cheese from dairy cows supplemented a diet with palm kernel cake. Molecules, Basel, v. 20, n. 8, p. 15434-15448, 2015.

ÖZKAN, S.; HILL, J.; CULLEN, B. Effect of climate variability on pasture-based dairy feeding systems in South-east Australia. Animal Production Science, Queensland, v. 55, n. 9, p. 1106-1116, 2014.

ROHWEDER, D.A., R.F. BARNES, and N. JORGENSEN. Proposed hay grading standards based on laboratory analyses for evaluating quality. Journal of Animal Science, v.47, p.747-759, 1978. 
SILVA, A. M.; OLIVEIRA, R. L.; RIBEIRO, O. L.; BAGALDO, A. R.; BEZERRA, L. R.; CARVALHO, S. T.; ABREU, C. L.; LEÃO, A. G. Valor nutricional de resíduos da agroindústria para alimentação de ruminantes. Comunicata Scientiae, Teresina, v. 5, n. 4, p. 370-379, 2015.

SILVA, D. J.; QUEIROZ, A. C. Análise de alimentos: métodos químicos e biológicos. Viçosa, MG: UFV, 2002. $235 \mathrm{p}$.

THEODOROU, M. K.; WILLIAMS, B. A.; DHANOA, M. S.; MCALLAN, A. B.; FRANCE, J. A simple gas production method using a pressure transducer to determine the fermentation kinetics of ruminant feeds. Animal Feed Science and Technology, Madrid, v. 48, n. 3-4, p. 185-197, 1994.
VAN SOEST, P. J.; ROBERTSON, J. B.; LEWIS, B. A. Methods for dietary fiber, neutral detergent fiber, and non starch polyssacharides in relation to animal nutrition. Journal of Dairy Science, Illinois, v. 74, n. 10, p. 35833597, 1991.

WILSON, G. L.; DALZELL, B. J.; MULLA, D. J. Estimating water quality effects of conservation practices and grazing land use scenarios. Journal of Soil and Water Conservation, Fort Collins, v. 69, n. 4, p. 330-342, 2014.

ZHANG, Q.; LI, X.; ZHAO, M.; YU, Z. Lactic acid bacteria strains for enhancing the fermentation quality and aerobic stability of Leymus chinensis silage. Grass Forage Science, Londres, v. 71, n. 3, p. 472-481, 2016. 
